\title{
Eicosapentaenoic Acid (EPA) Reduces Cardiovascular Events: Relationship with the EPA/Arachidonic Acid Ratio
}

\author{
Haruo Ohnishi ${ }^{1}$ and Yasushi Saito ${ }^{2}$
}

${ }^{1}$ Mochida Pharmaceutical Co. Ltd., Tokyo, Japan

${ }^{2}$ Chiba University Graduate School of Medicine, Chiba, Japan

\begin{abstract}
The clinical efficacy of fish oil and high-purity eicosapentaenoic acid ethyl ester (hp-EPA-E) for treating cardiovascular disease (CVD) has been reported. Fish oil contains saturated and monounsaturated fatty acids that have pharmacological effects opposite to those of $\omega 3$ fatty acids $(\omega 3)$. Moreover, $\omega 3$, such as EPA and docosahexaenoic acid (DHA), do not necessarily have the same metabolic and biological actions. This has obscured the clinical efficacy of $\omega 3$. Recently, the Japan EPA Lipid Intervention Study (JELIS) of hp-EPA-E established the clinical efficacy of EPA for CVD, and higher levels of blood EPA, not DHA, were found to be associated with a lower incidence of major coronary events. A significant reduction in the risk of coronary events was observed when the ratio of EPA to arachidonic acid (AA) (EPA/AA) was $>0.75$. Furthermore, the ratio of prostaglandin (PG) $\mathrm{I}_{3}$ and $\mathrm{PGI}_{2}$ to thromboxane $\mathrm{A}_{2}\left(\mathrm{TXA}_{2}\right)\left(\left[\mathrm{PGI}_{2}+\mathrm{PGI}_{3}\right] / \mathrm{TXA}_{2}\right)$ was determined to have a linear relationship with the EPA/AA ratio as follows: $\left(P G I_{2}+P G I_{3}\right) / T X A_{2}=\lambda+\pi *(E P A / A A)$. Like PGI $2, \mathrm{PGI}_{3}$ not only inhibits platelet aggregation and vasoconstriction, but also is assumed to reduce cardiac ischemic injury and arteriosclerosis and promote angiogenesis. Thus, the effects of EPA in reducing the risk of CVD could be mediated by biological action of $\mathrm{PGI}_{3}$ in addition to hypotriglyceridemic action of EPA. Compared with DHA, EPA administration increases the EPA/AA ratio and the $\left(\mathrm{PGI}_{2}+\mathrm{PGI}_{3}\right) / \mathrm{TXA}_{2}$ balance to a state that inhibits the onset and/or progression of CVD.
\end{abstract}

J Atheroscler Thromb, 2013; 20:861-877.

Key words: EPA, PGI 3 , Cardiovascular disease, PGI/TXA balance, EPA/AA ratio

\section{Introduction}

Numerous clinical trials have demonstrated the effects of oral preparations (fish oil and purified $\omega 3$ fatty acids [ $\omega 3]$ ) in preventing and treating various diseases. However, the effects of $\omega 3$, such as eicosapentaenoic acid (EPA) and docosahexaenoic acid (DHA), have not been differentiated in most fish oil studies, even though these effects are not necessarily alike. Therefore, elucidating the different mechanisms of action of EPA and DHA could lead to substantial improvement in the therapeutic use of fish oil ${ }^{1)}$. Clinical trials of fish oil have obscured the understanding

Address for correspondence: Haruo Ohnishi, Mochida Pharmaceutical Co., LTD, 7, Yotsuya 1-chome, Shinjuku-ku, Tokyo, Japan

E-mail: haruo.onishi@mochida.co.jp

Received: January 20, 2013

Accepted for publication: June 17, 2013 of the physiological and pharmacological roles and health benefits of each $\omega 3^{2)}$.

In response to a meta-analysis of fish oil clinical studies ${ }^{3)}$, Tolonen et al. commented that fish oils contain only approximately $50 \% \omega 3$, while the remaining fatty acids, such as AA and EPA, antagonize each other, and such interactions have not been examined ${ }^{4}$. Saturated and monounsaturated fatty acids that have pharmacological effects opposite to those of $\omega 3$ are often present as minor components in fish oil. In contrast, many in vitro experiments have not considered the fact that EPA is metabolized to prostaglandin $\mathrm{I}_{3}$ $\left(\mathrm{PGI}_{3}\right)$ with high bioactivity in vivo, another factor complicating the evaluation of $\omega 3$.

Based on these considerations and the results of purified $\omega 3$ studies and clinical trials of the hazard ratios (HRs) of fatty acids for major coronary events, the effects of EPA on cardiovascular events have been clarified, and the mechanism of action of EPA has 
been studied. Both the pharmacological effects of DHA on the cardiovascular system and the clinical efficacy of preparations primarily containing DHA and EPA suggest that DHA decreases the risk of cardiovascular events. However, it is unknown whether DHA makes a major contribution to the clinical efficacy observed in clinical trials, as, to the best of our knowledge, there have been no interventional trials involving purified DHA only.

\section{Origins of Clinical Research}

In 1959, it was found that orally ingested herring oil (EPA concentration: 12.5\%, DHA concentration: $8.9 \%)$ reduces the blood cholesterol and triglyceride (TG) levels ${ }^{5}$. In 1961, a reduction in the blood lipid levels was reported after the ingestion of herring oil fraction (EPA concentration: 24\%, DHA concentration: $35 \%)^{6}$. Another study reported that the adipose tissue of individuals consuming large amounts of fish contained high levels of C:20 fatty acids ${ }^{7}$. In 1972, Nelson reported that long-term seafood consumption by heart disease patients appeared to extend the average life span of the patients ${ }^{8}$. Based on findings reported in 1971 and 1975, Dyerberg et al. hypothesized that the lower incidence of cardiac disease, arteriosclerosis and myocardial infarction observed in the Inuit population compared to Danish individuals was associated with low blood cholesterol and TG levels and high blood EPA levels ${ }^{9,10)}$. These findings led to a number of studies that examined the effects of fish oil and high-purity $\omega 3$ on hyperlipidemia and cardiovascular and other events, focusing on the involvement of EPA and DHA.

\section{The Hypothesis of Dyerberg et al. Regarding the Association between the Blood EPA Levels and Cardiovascular Events}

A series of studies by Dyerberg et al. prompted numerous reports of the efficacy of fish oil and highpurity EPA in the treatment of various diseases. In 1971, Dyerberg et al. noted that the levels of blood cholesterol, TGs and $\beta$-lipoprotein were lower in the Greenland Inuit than in Danes and that the Inuit diet consisted of a large amount of marine animals and fish, suggesting that this diet was responsible for the low incidence of cardiac disease in the Inuit ${ }^{9)}$.

In 1975, Dyerberg et al. compared the fatty acid composition of blood from the Inuit with that of Danes. Regardless of the lipid type, the blood EPA levels were significantly higher in the Inuit than in the Danes and the levels of AA in cholesterol esters and
Table 1. Fatty acid compositions of plasma phospholipids of Inuit and Danes ${ }^{10)}$

\begin{tabular}{cccc}
\hline Fatty acid & $\begin{array}{c}\text { Inuit in } \\
\text { Greenland }\end{array}$ & $\begin{array}{c}\text { Caucasian } \\
\text { Danes }\end{array}$ & $p$ \\
\hline $14: 0$ & 0.08 & 0.18 & $\leqq 0.001$ \\
$14: 1$ & 0.00 & 0.08 & $\leqq 0.001$ \\
$16: 0$ & 34.87 & 30.59 & $\leqq 0.01$ \\
$16: 1$ & 2.68 & 0.77 & $\leqq 0.001$ \\
$17: 0$ & 0.00 & 0.47 & $\leqq 0.001$ \\
$18: 0$ & 19.56 & 17.21 & $\leqq 0.01$ \\
$18: 2$ & 6.58 & 20.95 & $\leqq 0.001$ \\
$18: 3$ & 0.00 & 0.50 & $\leqq 0.001$ \\
$20: 1$ & 2.73 & 0.00 & $\leqq 0.001$ \\
$20: 4$ & 0.81 & 7.99 & $\leqq 0.001$ \\
$20: 5$ & 7.11 & 0.16 & $\leqq 0.001$ \\
$22: 0$ & 0.69 & 0.00 & $\leqq 0.05$ \\
$22: 6$ & 3.92 & 3.04 & $\mathrm{NS}$ \\
$24: 0$ & 2.12 & 0.00 & $\leqq 0.001$ \\
\hline
\end{tabular}

Relative value, percent.

phospholipids were significantly lower, whereas the DHA levels were lower in cholesterol esters and TGs and higher in phospholipids. The authors drew attention to the fact that one of the most notable differences between the Inuit and Danes was the high blood EPA content and the high consumption of marine foods by the Inuit ${ }^{10)}$ (Table $\mathbf{1}$ ).

In 1976, Dyerberg et al. reported that, compared to Danes, the Inuit consumed a high-protein, low-carbohydrate diet; whereas, fat consumption was more or less the same in both groups.

However, the fat consumed by the Inuit contained higher concentrations of long-chain polyunsaturated fatty acids, especially EPA, and lower concentrations of linoleic and linolenic acids, suggesting that the low blood cholesterol levels observed in the Inuit were due to the effects of consuming long-chain polyunsaturated fatty acids derived from marine mammals. A similar effect on the blood TG and low-density lipoprotein (LDL) levels may play an important role in differences in the onset of coronary artery atherosclerosis $^{11)}$.

In 1978, Dyerberg et al. proposed that the Inuit, who have higher blood EPA levels and lower AA levels than Danes, have a low incidence of myocardial infarction but are prone to hemorrhage, suggesting that foods rich in EPA prevent clot formation. Because EPA, unlike AA, does not induce the aggregation of platelets, high EPA and low AA levels result in an antithrombogenic state ${ }^{12)}$. In 1986, it was reported that high blood EPA and low AA levels result in the 
Table 2. Influences of administration of highly purified EPA-E on blood fatty acid levels and their hazard ratio for major coronary events ${ }^{21}$

\begin{tabular}{llccc}
\hline \multicolumn{2}{c}{ Fatty Acid $(\mu \mathrm{g} / \mathrm{mL}$ : mean $)$} & \multicolumn{2}{c}{ Hazard Ratio $(95 \% \mathrm{CI})$} \\
\hline Control & Palmitic Acid & $(736)$ & $0.89(0.60-1.34)$ & $p=0.586$ \\
& Stearic Acid & $(227)$ & $0.73(0.50-1.07)$ & $p=0.103$ \\
Oleic Acid & $(678)$ & $1.18(0.80-1.73)$ & $p=0.401$ \\
Linoleic Acid & $(825)$ & $1.33(1.02-1.74)$ & $p=0.039$ \\
AA & $(168)$ & $0.90(0.69-1.16)$ & $p=0.415$ \\
EPA & $(95)$ & $0.83(0.62-1.10)$ & $p=0.186$ \\
& DHA & $1.22(0.91-1.65)$ & $p=0.187$ \\
\hline EPA Group & $(165)$ & $1.16(0.72-1.86)$ & $p=0.543$ \\
& Palmitic Acid & $(710)$ & $0.74(0.48-1.12)$ & $p=0.148$ \\
& Stearic Acid & $(224)$ & $0.88(0.55-1.39)$ & $p=0.571$ \\
Oleic Acid & $(634)$ & $1.12(0.82-1.53)$ & $p=0.469$ \\
Linoleic Acid & $(773)$ & $0.86(0.64-1.17)$ & $p=0.336$ \\
AA & $(152)$ & $0.71(0.54-0.94)$ & $p=0.018$ \\
EPA & $(170)$ & $0.88(0.64-1.20)$ & $p=0.414$ \\
\hline
\end{tabular}

increased production of $\mathrm{PGI}_{3}$ and $\mathrm{PGI}_{2}$ and the reduced production of thromboxane (TX) $\mathrm{TXA}_{2}$ and $\mathrm{TXA}_{3}$. Consequently, the balance between PGI and TXA (PGI/TXA), which may play a role in regulating the interaction between platelets and the vascular wall, shifts in a manner that may explain the lower incidence of thrombosis in the Inuit ${ }^{13)}$.

In summary, the major difference in the fatty acid composition of blood lipid fractions between the Inuit and Danes lies in the rich presence of EPA in the blood of the Inuit, which may contribute to the low rates of cardiac disease and arteriosclerosis observed in this population. This conclusion is supported by the findings of Kromann et al., who found that three of 1,800 Inuit living in the Upernavik district of Greenland died of myocardial infarction between 1950 and 1974, whereas the corresponding number of deaths among Danes during the same period was estimated to be approximately $40^{14)}$.

In Japan, a series of studies by Hirai et al. found results matching those of Dyerberg et al. In 1980, the blood fatty acid composition and platelet adhesiveness were compared between the residents of fishing and farming villages ${ }^{15)}$, and subsequently, in 1985, the mortality among patients with cardiovascular disease (CVD) was examined ${ }^{16)}$. The residents of the fishing villages exhibited significantly higher levels of blood EPA, DHA and AA and higher blood EPA/AA ratios. In addition, their adenosine diphosphate levels, which induce platelet adhesiveness, were 3-fold higher than those of the individuals from the farming villages, clearly indicating that platelet adhesiveness was accel- erated in the latter group. Furthermore, the adjusted mortality rate from CVD was higher in the farming district than in the fishing district.

In line with the findings of Dyerberg et al., Hirai et al. concluded that the consumption of $\omega 3$, specifically EPA, is useful for preventing and treating thrombosis and arteriosclerosis ${ }^{16)}$. Subsequently, the theory of Dyerberg et al. was confirmed epidemiologically among Japanese individuals who consume large amounts of fish. The relationship between 13 intake and cardiac disease, estimated based on fish consumption, was also investigated in the USA. During a 6- to 8-year follow-up, a significant correlation was observed between $\omega 3$ (EPA + DHA + docosapentaenoic acid [DPA]) intake and death from cardiac disease in 12,866 patients with risk factors for cardiac disease ${ }^{17)}$. Iso $e t a l$. also reported that an increased intake of fish and $\omega 3$ reduced the relative risk of stroke in 79,839 nurses without a history of CVD, cancer, diabetes or hypercholesterolemia ${ }^{18)}$. These studies suggest a negative correlation between $\omega 3$ intake and the incidence or mortality associated with CVD.

\section{Effects of the Administration of Fish Oil or High-Purity EPA Ethyl Ester (hp-EPA-E) on Cardiovascular Events}

A few large studies using fish oil containing highconcentration EPA and DHA and hp-EPA-E have confirmed the effects of $\omega 3$ on cardiovascular events. The GISSI-HF trial reviewed the effects of fish oil in patients with chronic cardiac failure (New York Heart 
Association classes II-IV). The incidence of all-cause death and hospitalization due to CVD was $59.0 \%$ in the placebo group and $56.7 \%$ in the fish oil group (1 g/day, EPA-E and DHA-E: 850-882 mg, EPA/DHA: 1/1.2) (hazard ratio [HR]: 0.92, $p=0.009$ ), with median 3.9-year follow-up, suggesting that the administration of fish oil helped to reduce the number of deaths and episodes of chronic cardiac failure. At three years, the median blood TG level was slightly decreased from $1.42 \mathrm{mmol} / \mathrm{L}$ at baseline to 1.34 $\mathrm{mmol} / \mathrm{L}$; however, no changes were observed in the total cholesterol, high-density lipoprotein or LDL levels ${ }^{19)}$.

In the Japan EPA Lipid Intervention Study (JELIS), the effects of an hp-EPA-E preparation (Epadel $^{\circledR}$, purity: $>98 \%$, Tokyo, Japan) on coronary events in patients with hypercholesterolemia were investigated for an average of 4.6 years. The hp-EPA-E group received $1.8 \mathrm{~g} /$ day of hp-EPA-E and statins, while the control group was given statins only. Major coronary events were observed in $2.8 \%$ of the subjects in the hp-EPA-E group and $3.5 \%$ of the subjects in the control group, with a significant risk reduction of $19 \%$ in the hp-EPA-E group. The risk of the primary end point was reduced, although not significantly, by $18 \%$ in the hp-EPA-E group; however, it was reduced significantly (19\%) during the secondary prevention evaluation ${ }^{20)}$.

\section{Relationship between Cardiovascular Events and Blood Fatty Acids}

Although the above-mentioned results demonstrated that ichthyophagi or the administration of fish oil and/or hp-EPA-E preparations reduces the frequency of cardiovascular events, the relationship between increased blood $\omega 3$ levels and the incidence of cardiovascular events remains unclear. However, a few recent studies have focused on this issue. In the JELIS trial, higher blood EPA levels in the EPA-E group were associated with a lower incidence of main coronary events (HR: $0.71, p=0.018$ ). No such relationships were observed for the blood DHA levels ${ }^{21)}$ (Table 2).

These findings demonstrate that EPA can prevent coronary events. The JELIS study both scientifically and directly validated the prescience of Dyerberg et al. that EPA can control the occurrence of cardiovascular events. Mozaffarian et al. examined the relationship between the onset of congestive cardiac failure and the EPA, DHA and DPA levels in blood phospholipids in healthy adults $\geq 65$ years of age. A multivariate analysis demonstrated a negative correla- tion between the EPA levels in blood phospholipids and the onset of cardiac failure; the risk of cardiac failure in the subjects in the top EPA level quartile was approximately $50 \%$ lower than that in the patients in the bottom quartile (HR: $0.52, p=0.001$ ). A trend toward a lower risk was observed for DPA (HR: 0.76, $p=0.057$ ) but not DHA (HR: 0.84, $p=0.38$ ), suggesting that the EPA in blood phospholipids controls the onset of congestive cardiac failure in healthy adults. For EPA and DHA, the 6- and 13-year correlations with the baseline levels of blood phospholipids were comparable to those of blood pressure ${ }^{22)}$. Lee et al. analyzed the relationship between mortality after myocardial infarction and the blood phospholipid EPA and DHA levels. With respect to cardiovascular death, the blood EPA HR was $0.41(p=0.005)$ and the blood DHA HR was 0.84 . This finding demonstrates that higher EPA levels are associated with a reduction in the incidence of cardiovascular death in myocardial infarction patients ${ }^{23)}$.

Domei et al. reported that univariate analyses of hazardous cardiac events in patients undergoing percutaneous coronary intervention (PCI) yielded an HR of $0.54(p=0.031)$ for blood EPA, $0.59(p=0.060)$ for DHA, $0.50(p=0.013)$ for the EPA/AA ratio and $0.65(p=0.127)$ for the DHA/AA ratio, indicating that higher EPA levels or EPA/AA ratios, but not DHA levels or DHA/AA ratios, are associated with a reduction in the incidence of hazardous cardiac events ${ }^{24)}$.

In summary, these findings demonstrate that higher blood EPA levels are associated with a reduction in the onset of congestive cardiac failure in healthy adults, coronary events in patients with hyperlipidemia and mortality in patients with myocardial infarction. However, a study examining the relationship between the blood fatty acid levels at baseline and the risk of developing cardiac failure in Caucasians with no history of cardiac disease, stroke or cardiac failure revealed findings that differed from the aforementioned results. The HR for long-chain $\omega 3$ in phospholipids was $0.24(p<0.001)$ in women and $0.99(p=0.43)$ in men, while that for EPA was 1.61 $(p=0.06)$ and that for DHA was $0.16(p<0.001)$ in women and $1.17(p=0.51)$ in men. There was a negative correlation between the $\omega 3$ and DHA levels and cardiac failure in women ${ }^{25)}$. The reasons for the differences between these findings are not known. However, it is possible that the fatty acid concentrations varied due to the subjects' lifestyle changes during the 14.3year follow-up, given that the correlations between the 14.4-year and baseline EPA and DHA levels were not studied, unlike the study by Mozaffarian et al. ${ }^{22}$. 


\section{Differences between EPA and DHA}

As described in the preceding sections, the relationship between the occurrence of cardiovascular events and the blood EPA levels is not identical with that for DHA. This difference is entirely or partially due to the resulting integrating differences in the distribution of these compounds in both tissue and membrane phospholipid subclasses and in their metabolites.

\section{Subclasses of Platelet Phospholipids}

The phosphatidylcholine (PC), phosphatidylethanolamine (PE), phosphatidylserine (PS) and phosphatidylinositol (PI) content in human platelets is $568.65,429.49,161.92$ and $61.55 \mathrm{nmol}$ phosphorus $/ 5 \times 10^{9}$ cells, respectively ${ }^{26}$. When ${ }^{14} \mathrm{C}$-EPA is incubated with platelets, ${ }^{14} \mathrm{C}$-EPA is incorporated at $67.0 \%$, $13.1 \%, 13.9 \%$ and $2.9 \%$ into PC, PE, PI and PS, respectively. When ${ }^{14} \mathrm{C}$-DHA is incubated with platelets, ${ }^{14} \mathrm{C}$-DHA is incorporated at $37.0 \%, 45.2 \%, 7.5 \%$ and $1.6 \%$ into PC, PE, PI and PS, respectively. When ${ }^{14} \mathrm{C}$-AA is incubated with platelets, ${ }^{14} \mathrm{C}$-AA is incorporated at $62.1 \%, 11.8 \%, 20.6 \%$ and $3.4 \%$ into PC, PE, PI and PS, respectively. Compared to DHA, EPA and $\mathrm{AA}$ are much more significantly incorporated into $\mathrm{PC}$ and less into PE. Thrombin releases $0.2 \%$ of incorporated ${ }^{14} \mathrm{C}$-DHA, $13.4 \%$ of ${ }^{14} \mathrm{C}$-EPA and $19.1 \%$ of ${ }^{14} \mathrm{C}$-AA from platelets ${ }^{27)}$. In platelets from human subjects who ingest fish oil, the AA concentrations in PC, PE, PI, and PS are 76.5, 120.5, 31.2, and 39.8 $\mathrm{nmol} /$ platelet, respectively. Thrombin causes losses of 20.3, 7.4, 14.8 and $<1.6 \mathrm{nmol} /$ platelet $\mathrm{AA}$ in $\mathrm{PC}$, $\mathrm{PE}, \mathrm{PI}$ and PS, respectively. $\mathrm{PGI}_{2}$ is primarily generated from the AA of PC. The EPA concentrations in platelet PC, PE, PI and PS are 22.1, 26.6, 0.7 and 1.6 nmol/platelet, respectively. Thrombin loses 5.2 and $2.0 \mathrm{nmol} /$ platelet of EPA in PC and PE, respectively. PC-derived EPA contributes to $\mathrm{PGI}_{2}$ generation ${ }^{28)}$. The ${ }^{3} \mathrm{H}-\mathrm{AA} /{ }^{14} \mathrm{C}-\mathrm{EPA}$ ratio of $\mathrm{PC}$ in platelets doublelabeled with ${ }^{3} \mathrm{H}-\mathrm{AA}$ and ${ }^{14} \mathrm{C}$-EPA is unaltered by the stimulation of thrombin, while AA and EPA in PC are released nonselectively ${ }^{29)}$. Although $37.0 \%$ of ${ }^{14} \mathrm{C}$ DHA is incorporated into PC, only $0.2 \%$ of ${ }^{14} \mathrm{C}$ DHA is released by thrombin. These findings suggest the following: Platelets have an abundance of PC that contains much AA, and much AA is stored in PC and metabolizes to TXA or PI if the need arises. To replenish the consumed AA in PC adequately, AA is very efficiently incorporated by acyl-CoA: lysophosphatidylcholine acyltransferase ${ }^{30)}$. As EPA is also metabolized to TXA and PI, it is efficiently incorporated, as well as AA, but not DHA. This conclusion is in agreement with the findings of Iritani et al. In platelets, the acyl-donor specificity of the enzyme for 1-acyl-glycerophosphorylcholine is as follows: arachidonyl-CoA $>$ eicosapentaenoyl-CoA $>$ linoleyl-CoA $>$ docosahexaenoyl-CoA $>$ palmitoyl-CoA ${ }^{31)}$.

\section{Phospholipid Subclasses in the Vascular Endothelial Cell Membrane}

Cultured human umbilical arterial endothelial cell membrane phospholipids are constituted by PC (49.0 mol\%), PE (28.1 mol\%), PS (9.0 mol\%), PI $(6.0 \mathrm{~mol} \%)$ and others ${ }^{32}$. The composition of human vascular endothelial cells is similar ${ }^{33)}$. More PC appears to exist in endothelial cell membrane phospholipids than in platelets. Following incubation, $62 \%, 12 \%$ and $10 \%$ of ${ }^{14} \mathrm{C}$-EPA and $57 \%, 11 \%$ and $26 \%$ of ${ }^{3} \mathrm{H}-\mathrm{AA}$ are incorporated into the $\mathrm{PC}, \mathrm{PE}$ and PI, respectively, of bovine thoracic aorta endothelial cells ${ }^{34)}$. These results are similar to those obtained in platelets. For PGI 2 synthesis, $16.2 \%$ of incorporated ${ }^{3} \mathrm{H}-\mathrm{AA}$ is released from cultured vascular endothelial cell membranes; the rest is released from PI (3.4\%), PE $(3.5 \%)$ and PC $(9.3 \%)^{35)}$. These results show that both AA and EPA are metabolized to $\mathrm{PGI}_{2}$ or $\mathrm{PGI}_{3}$ through similar pathways in vascular endothelial cells, in which the PC of the blood membrane plays an important role. It has been suggested that differences in EPA and DHA distributions in phospholipid subclasses contribute to the differing clinical effects of EPA and DHA.

\section{Tissue $\omega 3$ Levels}

$\omega 3$ exist as constituents of cell membrane phospholipids. DHA is found in all organs and is abundant in nerve tissues, such as the cerebral cortex, hippocampus and retina, at concentrations that are several hundred times higher than those of EPA. In contrast, the EPA concentrations are only one-fifth to one-thirtieth of those of DHA in organs other than the brain and retina ${ }^{36)}$ (Fig. 1). The fact that DHA is present in large quantities in nerve tissue suggests that the physiological roles of EPA and DHA are not necessarily identical and that DHA may not influence the cardiovascular system.

\section{Effects of $\omega 3$ Administration on the Blood $\omega 3$ Levels}

Hansen et al. administered either EPA-E (95\% purity) or DHA-E (90\% purity) to healthy volunteers 


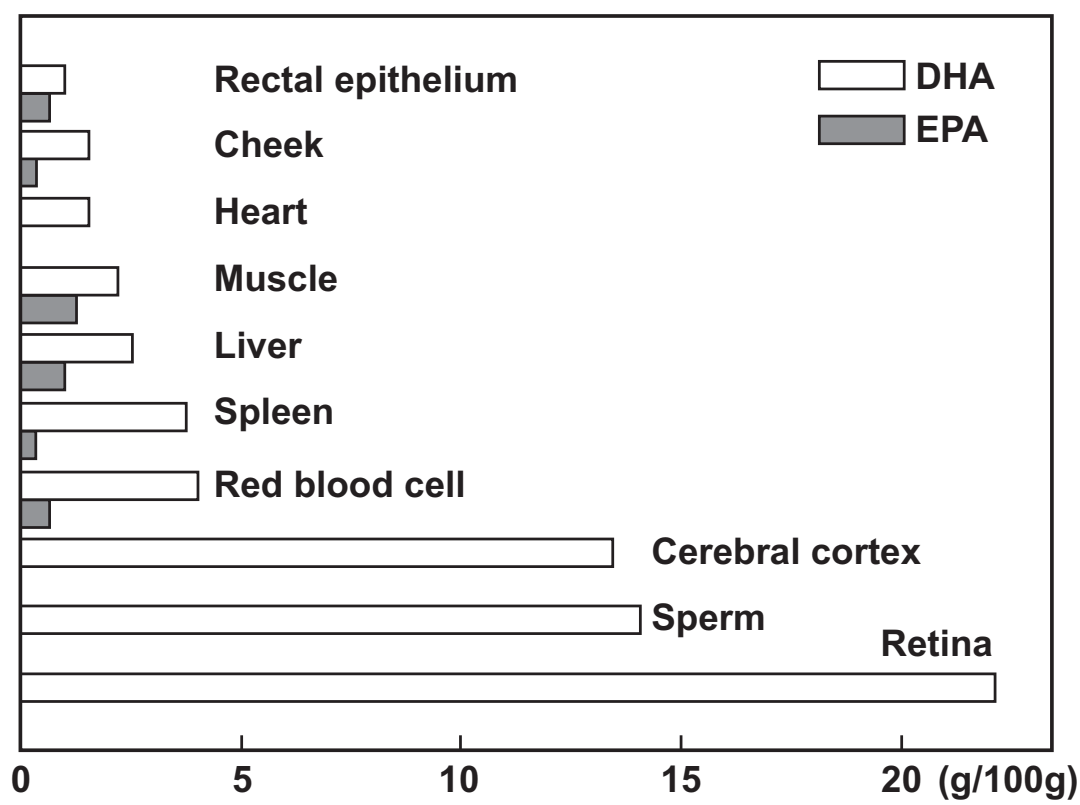

Fig. 1. Cross-study analysis of fatty acid concentrations (g/100 g of total fatty acids) in tissues from adults from the United State, Canada, Australia or Euroe $^{36)}$.

for five weeks. In the EPA-treated subjects, the EPA levels in blood phospholipids rose rapidly, whereas those of DHA decreased slightly. In contrast, the increase in the blood phospholipid DHA levels in the DHA-treated subjects was small, occurring at a moderate rate as compared to the increase in EPA, and the EPA levels increased only moderately. Although the mechanisms have not been elucidated, EPA incorporation into blood phospholipids indicates the priority of EPA in the circulatory pool, with DHA being taken up into the extracirculatory pool, implying that EPA and DHA undergo different processes of metabolism $^{37)}$ (Fig. 2). In a similar 6-week study, $4 \mathrm{~g}$ /day of EPA-E (96\% purity) or DHA-E (92\% purity) was administered in patients with mild hypercholesterolemia. The EPA-E increased the plasma phospholipid EPA levels and decreased the AA levels, while the DHA levels remained unchanged. In contrast, DHA-E increased the blood phospholipid DHA levels, while the AA levels decreased and the EPA levels slightly increased $^{38)}$ (Fig. 3).

In the JELIS study, $1.8 \mathrm{~g} /$ day of hp-EPA-E (Epadel ${ }^{\circledR}$ ) resulted in increases in the blood EPA levels from $97 \mu \mathrm{g} / \mathrm{mL}$ to $166 \mu \mathrm{g} / \mathrm{mL}$ and the EPA/AA ratio from 0.599 to 1.085 ; the DHA levels decreased from $170 \mu \mathrm{g} / \mathrm{mL}$ to $156 \mu \mathrm{g} / \mathrm{mL}$, and the AA levels decreased from $162 \mu \mathrm{g} / \mathrm{mL}$ to $153 \mu \mathrm{g} / \mathrm{mL}^{39)}$. The administration of algae-derived DHA (39\% purity; $1.62 \mathrm{~g} /$ day) altered the blood phospholipid EPA, DHA, AA and
EPA/AA values from $0.57 \mathrm{~g} / 100 \mathrm{~g}$ to $1.3 \mathrm{~g} / 100 \mathrm{~g}, 2.4$ $\mathrm{g} / 100 \mathrm{~g}$ to $8.3 \mathrm{~g} / 100 \mathrm{~g}, 9.7 \mathrm{~g} / 100 \mathrm{~g}$ to $6.5 \mathrm{~g} / 100 \mathrm{~g}$ and 0.06 to 0.19 , respectively ${ }^{40)}$. Arterburn et al. derived DHA dosage-blood concentration curves from the numerous DHA studies in humans. The blood phospholipid DHA levels increased with a higher DHA dosage, and saturation was observed at high doses. The EPA concentrations increased in a linear manner ${ }^{38)}$, matching the results of Hansen et al. mentioned above.

The increase in the blood EPA levels following the DHA administration was considered to have been be due to reverse conversion from DHA. The reverse conversion rate in humans has been calculated to be $1.4 \%{ }^{41)}$. Dietary DHA and EPA have been found to downregulate the DPA to DHA conversion rate to $70 \%$, leading to the expectation that EPA administration does not result in an increase in the DHA lev$\mathrm{els}^{36)}$. Given the autonomous functions of DHA in the brain, retina and sperm, restricted DPA to DHA conversion may play a very important role ${ }^{42)}$. In artificially induced $\omega 3$-deficiency states, brain tissue membranes resist the decrease in the DHA levels ${ }^{43)}$. $\omega 3$ deprivation reduces the blood DHA levels by $89 \%$ and the brain DHA levels by $37 \%{ }^{44)}$. EPA to DHA conversion may be restricted in order to maintain constant DHA levels for nervous system signaling ${ }^{45)}$. Although the reason for this phenomenon is unknown, the following may be a potential cause. DHA is abun- 


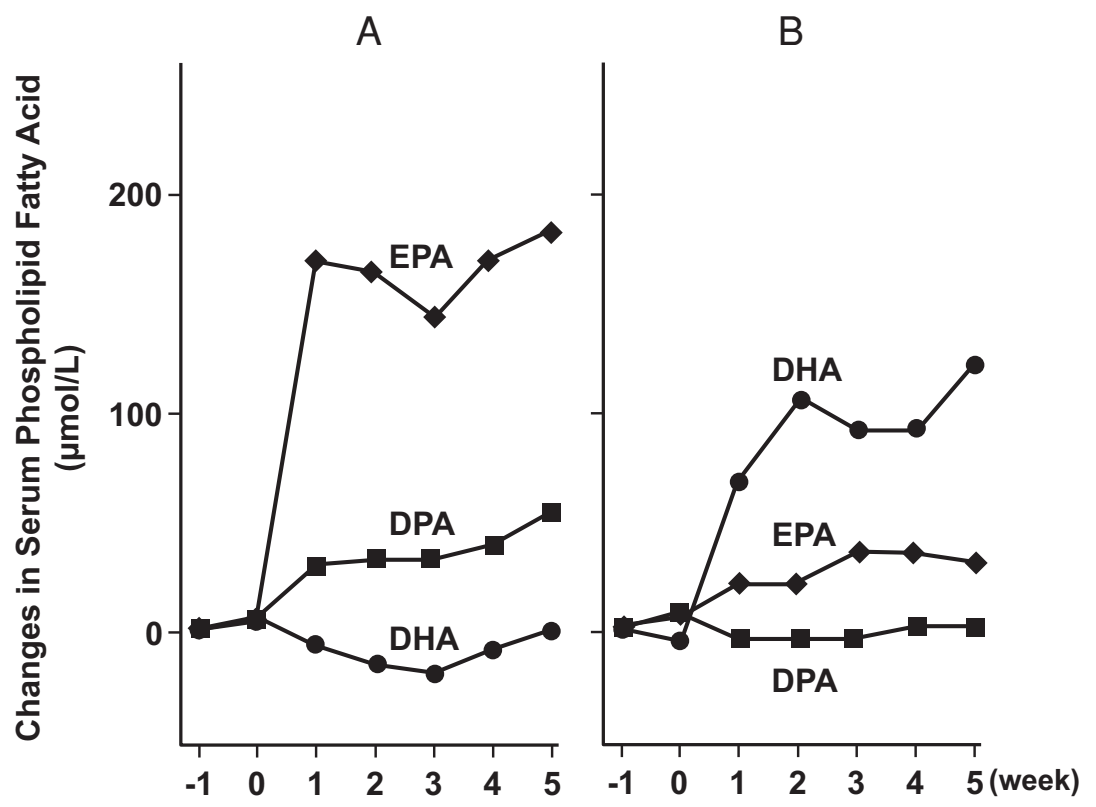

Fig. 2. Time course changes in human serum phospholipid $\omega 3$ fatty acid concentration after dietary intake of $4 \mathrm{~g}$ /day of EPA-E(95\% purity) (A) or DHA-E(90\% purity) (B) for 5 weeks ${ }^{37)}$.

dant in nervous tissue, and the oxidized DHA metabolite trans-4-hydroxy-2-hexenal (HHE) has been reported to exhibit neural toxicity. The concentration of $\mathrm{HHE}$ required for $50 \%$ cell death in primary cultures of cerebral cortical neurons is $23 \mu \mathrm{mol} / \mathrm{L}^{46}$. The extractable HHE level in the hippocampus/parahippocampal gyrus of normal control subjects is 11.3 $\mathrm{pmol} / \mathrm{mg}$ protein ${ }^{47)}$. This suggests that higher DHA levels than required result in nerve toxicity through metabolic oxidization in nerve tissue. If nonphysiological high doses of DHA are administered, the increase in the DHA levels is regulated to prevent high DHA levels in nerve tissue, which may result in saturation.

In summary, the blood EPA levels increase following EPA administration, whereas the DHA and AA levels remain unchanged or decrease. DHA administration results in a substantial increase in the blood DHA levels, with a slight increase in the EPA levels and decrease in the AA levels.

\section{Effects of $\omega 3$ Administration on the $\omega 3$ Levels in the Blood Vessel Walls}

Fish oil (EPA:14.3\%, DHA:8.3\%) was administered at a dose of $4 \mathrm{~g} /$ day for 7-189 days in patients scheduled to undergo carotid endarterectomy. Compared to the baseline values, the EPA and DHA levels in carotid plaque phospholipids increased by $83 \%$ and $9 \%$, respectively, whereas the AA levels decreased by only $2 \%$. The EPA/AA ratio increased from 0.059 to $0.11^{48)}$. In similar patients, the administration of fish oil $\left(\right.$ Omacor $^{\circledR}, 1.55 \mathrm{~g} /$ day, EPA: $810 \mathrm{mg}$, DHA: 675 $\mathrm{mg}$ ) for 7-71 days resulted in carotid plaque phospholipid EPA and DHA increases of $100 \%$ and 13\%, respectively, whereas the AA levels remained unchanged ${ }^{49)}$. Both of these studies confirmed that the incorporation of EPA into carotid plaque is greater than that of DHA. Assuming that the fatty acid level in carotid plaque is similar to that in blood vessel walls, the administration of fish oil containing DHA will also encourage more efficient EPA incorporation into the blood vessel walls; moreover, the EPA will be metabolized to $\mathrm{PGI}_{3}$, which will contribute to inhibiting cardiovascular events.

\section{Effects of Administration on the Heart w3 Levels}

Fish oil (EPA: 30\%, DHA: 20\%, 1 g/day) was administered in cardiac transplantation patients for six months, during which the myocardium EPA and DHA levels increased by 3.3-fold and 1.5-fold, respectively . EPA incorporation into the heart muscle was greater than that of DHA. The EPA/AA ratios in the myocardium, blood and erythrocytes increased from $0.020,0.024$ and 0.42 to $0.078,0.087$ and 0.164 , respectively ${ }^{50)}$. Similarly, when fish oil (3 g EPA $+3 \mathrm{~g}$ DHA/day) was administered in patients scheduled for 

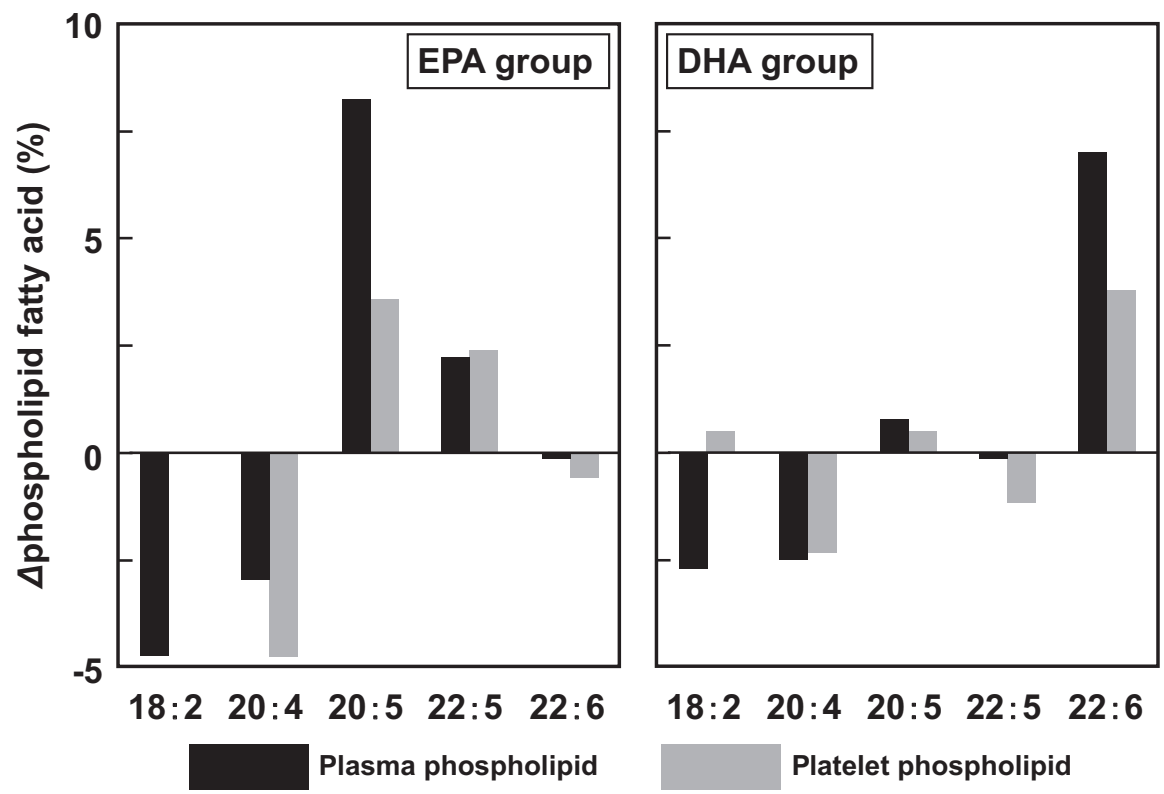

Fig. 3. Mean changes in human plasma and platelet phospholipid fatty acids from baseline to the end of the intervention with 4 g/day of EPA-E ( $96 \%$ purity) and DHA-E(92\% purity) for 6 weeks $^{38)}$.

coronary artery bypass grafting, the increase in EPA incorporation into the right atrium was greater than that of DHA at six months of follow-up ${ }^{51)}$. This result is similar to that observed in carotid plaque.

\section{Effects of $\omega 3$ Administration on the Platelet $\omega 3$ Levels}

Patients with mild hypercholesterolemia were administered $4 \mathrm{~g}$ /day of EPA-E (approximately 96\% purity) or DHA-E (approximately $92 \%$ purity) for six weeks. The administration of DHA and EPA increased the platelet phospholipid DHA levels by $54 \%$ (nonsignificant) and $370 \%$, respectively; however, the AA levels decreased by $15 \%$ and $7 \%$, respectively ${ }^{38)}$. The most important findings are as follows: in the EPAtreated patients, the EPA percentage increase was greater than the AA percentage decrease; and, in the DHA-treated patients, the AA percentage decrease was approximately half that observed in the EPA-treated patients, whereas the EPA levels remained almost unchanged. The administration of $1.8 \mathrm{~g} /$ day of hpEPA-E (Epadel ${ }^{\circledR}$ ) in patients with non-insulin-dependent diabetes mellitus for 14 weeks increased the platelet EPA levels from $2.26 \%$ to $3.66 \%$ (1.4\% increase); however, the AA levels decreased from $24.25 \%$ to $23.39 \%(0.86 \% \text { decrease })^{52)}$, confirming the results of Mori et al. ${ }^{38)}$ that the increase in the EPA levels exceeds the decrease in the AA levels. The administra- tion of fish oil (2 g/day; EPA-E: 46\%, DHA-E: 39\%) for 12 weeks resulted in an increase in the platelet EPA levels; however, both the DHA and AA levels remained almost unchanged ${ }^{53)}$.

In summary, EPA administration increases the platelet EPA levels more than it decreases the platelet AA levels. However, in DHA-treated patients, the degree of platelet AA decrease and EPA increase is smaller than that observed in EPA-treated patients. This finding indicates that the decrease in $\mathrm{TXA}_{2}$ synthesized in platelets is greater following EPA administration than following DHA administration.

\section{Bioactivity of $\omega 3$ Metabolites}

\section{PGI Bioactivity and EPA Actions}

In the vascular endothelial cell membrane, $\mathrm{PGI}_{2}$ and $\mathrm{PGI}_{3}$ are produced from phospholipid $\mathrm{AA}$ and EPA, respectively, whereas in platelets, $\mathrm{TXA}_{2}$ and $\mathrm{TXA}_{3}$ are produced from phospholipid AA and EPA, respectively. $\mathrm{PGI}_{2}$ inhibits platelet aggregation and promotes vasodilation, and the effects of $\mathrm{PGI}_{3}$ are equivalent to those of $\mathrm{PGI}_{2}{ }^{54}$ ). As $\mathrm{PGI}_{2}$ and $\mathrm{PGI}_{3}$ demonstrate both of these effects, it is logical to assume that the effects of $\mathrm{PGI}_{2}$ described below are also true of $\mathrm{PGI}_{3}$. However, the effects of $\mathrm{TXA}_{2}$ on platelet aggregation and vasoconstriction are not observed for $\mathrm{TXA}_{3}{ }^{55)}$. Therefore, in terms of the PGI/ TXA balance, $\mathrm{PGI}_{2}+\mathrm{PGI}_{3}$ should be used for PGI 
and TXA2 for TXA.

\section{Effects of PGI 2 and PGI 3 on the Vascular Tone}

$\mathrm{PGI}_{2}$ regulates the vascular tone via vasodilatation, and nitric oxide (NO) produced in vascular endothelial cells also regulates the vascular tone. In their physiological state, $\mathrm{PGI}_{2}$ and $\mathrm{NO}$ play complementary roles in vasodilation ${ }^{56)}$. At the same time, $\mathrm{PGI}_{2}$ regulates the endothelial function via crosstalk with endothelial nitric oxide synthase $(\mathrm{eNOS})^{57)}$. This indicates that $\mathrm{NO}$ activates $\mathrm{PGI}_{2}$ synthase and increases $\mathrm{PGI}_{2}$ production ${ }^{58)}$. It is believed that EPA-derived $\mathrm{PGI}_{3}$ is also involved in NO production. Furthermore, EPA increases NO production without $\mathrm{PGI}_{2}$ as follows: EPA modifies the lipid composition of the caveolae of endothelial cells, promotes the migration of caveolae-bound eNOS to the cytoplasm and finally activates $\mathrm{eNOS}^{59)}$.

\section{Effects of PGI 2 and $\mathrm{PGI}_{3}$ on Neoangiogenesis}

Neoangiogenesis is broadly divided into (1) angiogenesis in the narrow sense of the word, in which endothelial cells multiply from existing veins, migrate and form blood vessels, and (2) vasculogenesis, in which new blood vessels are formed from vascular endothelial progenitor cells (EPCs). In neoangiogenesis, growth factors, such as vascular endothelial growth factor (VEGF), hepatocyte growth factor (HGF) and basic fibroblast growth factor (bFGF), play important roles. These growth factors influence each other via $\mathrm{PGI}_{2}$. The production of VEGF, which plays an important role in neoangiogenesis, is induced by $\mathrm{PGI}_{2}{ }^{60)}$. The biosynthesis of PGI 2 in endothelial cells is promoted by $\mathrm{VEGF}^{61)}$, and EPCs promote the production of $\mathrm{PGI}_{2}$ by endothelial cells ${ }^{62)}$. In contrast, $\mathrm{TXA}_{2}$ receptor (TP) stimulation restricts neoangiogenesis by inhibiting the effects of VEGF ${ }^{63)}$. The HGF expression is upregulated by prostacyclin agonists ${ }^{64)}$. VEGF and bFGF increase endothelium-derived $\mathrm{PGI}_{2}$ production $^{65)}$.

Bone marrow-derived EPCs circulate in the body and support neoangiogenesis via the production of neoangiogenic factors ${ }^{66}$. EPCs release $\mathrm{PGI}_{2}$, and their neoangiogenic activity depends on the production of endogenous $\mathrm{PGI}_{2}{ }^{67)}$. EPCs are $\mathrm{PGI}_{2}$ receptor (IP)expressing cells; $\mathrm{PGI}_{2}$ enhances the functions of EPCs (adhesion to the extracellular matrix, migration and the regulation of vascular remodeling ${ }^{68)}$ and promotes neoangiogenesis, such as lumen formation, via the late differentiation of EPCs into endothelial cells ${ }^{67)}$. These views are supported by the following observations. The $\mathrm{PGI}_{2}$ analog, iloprost, increases circulating EPCs in patients with critical limb ischemia, demonstrating a curative effect ${ }^{69)}$. Dogs with myocardial ischemia exhibit a decreased infarction size and increased capillary density following the administration of hp-EPA-E and bone marrow mononuclear cells containing $\mathrm{EPCs}^{70)}$.

In addition, the clinical efficacy of hp-EPA-E in patients with arteriosclerosis obliterans has been reported $^{71)}$. This efficacy may be partially due to the angiogenic action of PGI3. Taken together, EPA as a precursor of $\mathrm{PGI}_{3}$ is suggested to promote neoangiogenesis. However, some experiments with cultured endothelial cells have indicated the role of EPA and DHA inhibition in neoangiogenesis. EPA markedly inhibits the tube-forming ability of endothelial cells, while DHA does not ${ }^{72}$. In addition, DHA attenuates endothelial cell tube formation ${ }^{73)}$. Spencer et al. suggested that these effects are due to the inhibition of the production of many angiogenic mediators, such as VEGF and $\omega 3$. In particular, EPA and DHA exhibit potent antiangiogenic effects, and opportunities for original research trials using $\omega 3$ as anticancer agents in humans have been identified ${ }^{74)}$.

\section{$\mathrm{PGI}_{2}$ and $\mathrm{PGI}_{3}$ in Arteriosclerosis}

Many studies have investigated the relationship between $\mathrm{PGI}_{2}$ and arteriosclerosis. If endothelial cells are damaged, $\mathrm{PGI}_{2}$ production decreases and $\mathrm{TXA}_{2}$ production increases, resulting in a cardiovascular cytotoxic response. After the collapse of the $\mathrm{PGI}_{2} /$ $\mathrm{TXA}_{2}$ balance, the inhibition of platelet adhesion to endothelial cells, platelet aggregation and vasodilatory effects of $\mathrm{PGI}_{2}$ are inundated by the actions of TXA2, causing platelet activation, coronary spasms and vascular smooth muscle cell (VSMC) proliferation that can result in arteriosclerosis and subsequently cardiovascular events. $\mathrm{PGI}_{2}$ inhibits platelet activation, leukocyte adhesion to the endothelium and VSMC proliferation in atherosclerotic plaque and prevents the progression of arteriosclerosis ${ }^{75)}$. Transfer of the $\mathrm{PGI}_{2}$ synthase gene controls the decrease in 6-ketoprostaglandin-F1 $\alpha$ (k-PGF1 $\alpha)$, increases $\mathrm{TXB}_{2}$ and localizes the neointimal growth caused by balloon injury ${ }^{76)}$. In IP-deficient mice, platelet aggregation and VSMC proliferation in response to vascular injury are accelerated, contributing to the progression of arteriosclerosis $^{77)}$. In contrast, platelet aggregation is inhibited in TP-deficient mice ${ }^{78)}$, while VSMC proliferation is decreased ${ }^{77)}$. Owing to the increase in TXA synthase in human arteriosclerosis lesions, $\mathrm{TXA}_{2}$ production by plaque tissue is thought to contribute to the progression of arteriosclerosis ${ }^{79)}$.

In summary, PGI2 inhibits the initiation and progression of atherosclerosis, whereas $\mathrm{TXA}_{2}$ promotes 
these phenomena ${ }^{80)}$. The role of $\mathrm{PGI}_{2}$ as a potent negative regulator of vascular remodeling and arteriosclerosis has been described ${ }^{77)}$. In EPA-treated mice, the vascular cell adhesion molecule-1 (VCAM-1) expression in endothelial cells is controlled, and monocyte adhesion to the endothelium is reduced. The administration of hp-EPA-E (Epadel ${ }^{\circledR}, 1.8 \mathrm{~g} /$ day) in patients with metabolic syndrome significantly decreases the blood levels of VCAM-1 and intercellular adhesion molecule-1 (ICAM-1) ${ }^{81)}$. The addition of EPA or DHA to endothelial cells inhibits the increased expression of adhesive factors (ICAM-1, VCAM- 1 and E-selectin) induced by interleukin $1 \beta^{82}$. The administration of $300 \mathrm{mg} /$ day of EPA-E significantly inhibits the proliferation of vascular membrane cells damaged by balloon injury ${ }^{83)}$. The administration of EPA or DHA increases systemic arterial compliance in patients with hyperlipidemia ${ }^{84}$. In conclusion, $\mathrm{PGI}_{3}$ and $\mathrm{PGI}_{2}$ mediate the anti-arteriosclerosis actions of EPA.

\section{$\mathrm{PGI}_{2}$ and $\mathrm{PGI}_{3}$ in Ischemic Heart Disease}

$\mathrm{PGI}_{2}$ is thought to protect the ischemic myocardium, whereas TXA 2 is believed to be harmful ${ }^{85)}$. $\mathrm{PGI}_{2}$ exerts direct protective effects on cardiac muscle cells that are not achieved via the control of platelets or neutrophils ${ }^{86)}$. This observation is supported by the finding of high $\mathrm{TXB}_{2}$ levels in the venous blood in ischemic regions in canine hearts following left anterior descending artery ligation, indicating that $\mathrm{TXA}_{2}$ promotes ischemic injury ${ }^{85)}$. In active-phase patients with angina, platelet IP is reduced and the inhibitory effects of $\mathrm{PGI}_{2}$ on platelet aggregation are weakened, whereas the IP count is recovered in inactive-phase patients ${ }^{87)}$. In IP-deficient mice, the size of the myocardial infarction caused by coronary artery ligation is significantly increased compared to that observed in wild-type mice, suggesting that $\mathrm{PGI}_{2}$ protects the myocardium from ischemia and reperfusion injury ${ }^{88)}$.

Meanwhile, the administration of hp-EPA-E $\left(\right.$ Epadel $\left.^{\circledR}\right)$ reduces neutrophil infiltration in ischemic regions caused by myocardial ischemia following left circumflex coronary artery ligation and reperfusion in pigs, thus helping to maintain the myocardial eNOS activity in the ischemic myocardium ${ }^{89)}$. EPA is thought to exert its anti-ischemic heart disease actions via $\mathrm{PGI}_{3}$.

\section{Tissue levels of $\omega 3$ metabolites}

\section{Balance between PGI and TXA and the Tissue Levels of $\omega 3$ Metabolites}

The PGI 2 metabolite 2,3-dinor-6-keto-PGF1 $\alpha$ is expressed as d-PGF1 $\alpha$, the $\mathrm{PGI}_{3}$ metabolite $\Delta 17-2,3$ -
dinor-6-keto-PGF1 $\alpha$ is expressed as $\triangle$-PGF $1 \alpha$, the $\mathrm{TXA}_{2}$ metabolite 11-dehydro- $\mathrm{TXB}_{2}$ is expressed as $\mathrm{d}-\mathrm{TXB}_{2}$ and the $\mathrm{TXB}_{3}$ metabolite 2,3 -dinor- $\mathrm{TXB}_{3}$ is expressed as $\mathrm{d}-\mathrm{TXB}_{3}$.

As described above, the bioactivities of PGI and TXA are not limited to platelet aggregation/antiaggregation and vasodilatation/relaxation, but rather are far more extensive. Based on these findings, it is necessary to consider the relationship between the PGI/TXA balance and the onset/progression of CVD. Extrinsic EPA reduces $\mathrm{PGI}_{2}$ production in human endothelial cells ${ }^{90)}$. However, most of the decrease in the $\mathrm{PGI}_{2}$ production is compensated for by the $\mathrm{PGI}_{3}$ generated by EPA in vascular cells ${ }^{91)}$. In contrast, PGI 2 analogs phosphorylate TP, thereby weakening the $\mathrm{TXA}_{2}$-associated platelet activity ${ }^{92)}$. $\mathrm{PGI}_{2}$ also reduces TXA production via platelet IP ${ }^{93)}$. This finding indicates that $\mathrm{PGI}_{2}$ and $\mathrm{PGI}_{3}$ control TXA production and actions. These results suggest that the role of $\mathrm{PGI}_{3}$ produced from EPA cannot be ignored when examining the relationship between the PGI/TXA balance and the onset/progression of CVD and that the (PGI $+\mathrm{PGI}_{3}$ )/TXA2 ratio is a more appropriate index than the $\mathrm{PGI}_{2} / \mathrm{TXA}_{2}$ ratio. This observation is in agreement with the above-mentioned hypothesis that, in terms of the PGI/TXA balance, $\mathrm{PGI}_{2}+\mathrm{PGI}_{3}$ must be used for PGI and TXA 2 for TXA.

Fisher et al. calculated the PGI/TXA ratio by taking into consideration the $\mathrm{PGI}_{3}$ metabolite levels while examining the differences in the thrombotic state between the Inuit and Danes. The urinary d-PGF1 $\alpha$ and $\mathrm{d}-\mathrm{TXB}_{2 / 3}$ levels were $0.146 \mathrm{ng} / \mathrm{mg}$ creatinine $(\mathrm{mgc})$ and $0.465 \mathrm{ng} / \mathrm{mgc}$, respectively, in the Inuit and 0.109 $\mathrm{ng} / \mathrm{mgc}$ and $0.754 \mathrm{ng} / \mathrm{mgc}$, respectively, in the Danes. The $\Delta$-PGF1 $\alpha$ excretion was $0.049 \mathrm{ng} / \mathrm{mgc}$ in the Inuit and below the detection limit in the Danes. Moreover, the (d-PGF $1 \alpha+\Delta \mathrm{PGF} 1 \alpha) / \mathrm{d}-\mathrm{TXB}_{2 / 3}$ ratio was 0.42 in the Inuit and 0.14 in the Danes, suggesting that the PGI/TXA balance was shifted to the antithrombogenic state ${ }^{13)}$. Similarly, the urinary (d-PGF1 $\alpha$ $+\Delta \mathrm{PGF} 1 \alpha) / \mathrm{d}-\mathrm{TXB}_{2 / 3}$ ratio in the Japanese farmers was 0.260 , which was lower than the 0.293 observed in the Japanese individuals from the fishing villages who ate a diet rich in fish ${ }^{94)}$. The effects of EPA or DHA administration on the $\left(\mathrm{PGI}_{2}+\mathrm{PGI}_{3}\right) / \mathrm{TXA}_{2}$ ratio are conceptually as follows. EPA administration results in a decrease in the cell membrane AA level, which reduces the production of TXA 2 and $\mathrm{PGI}_{2}$ and increases the cell membrane EPA level and thus the $\mathrm{PGI}_{3}$ level, resulting in the inhibition of platelet aggregation and vascular constriction. In contrast, DHA administration decreases the cell membrane AA level; however, as mentioned above, this decrease is smaller than that 
$\mathrm{TXA}_{2} \gg P \mathrm{PI}_{2}+\mathrm{PG} \mathrm{I}_{3}$

(State of Elevated CVD Risk)

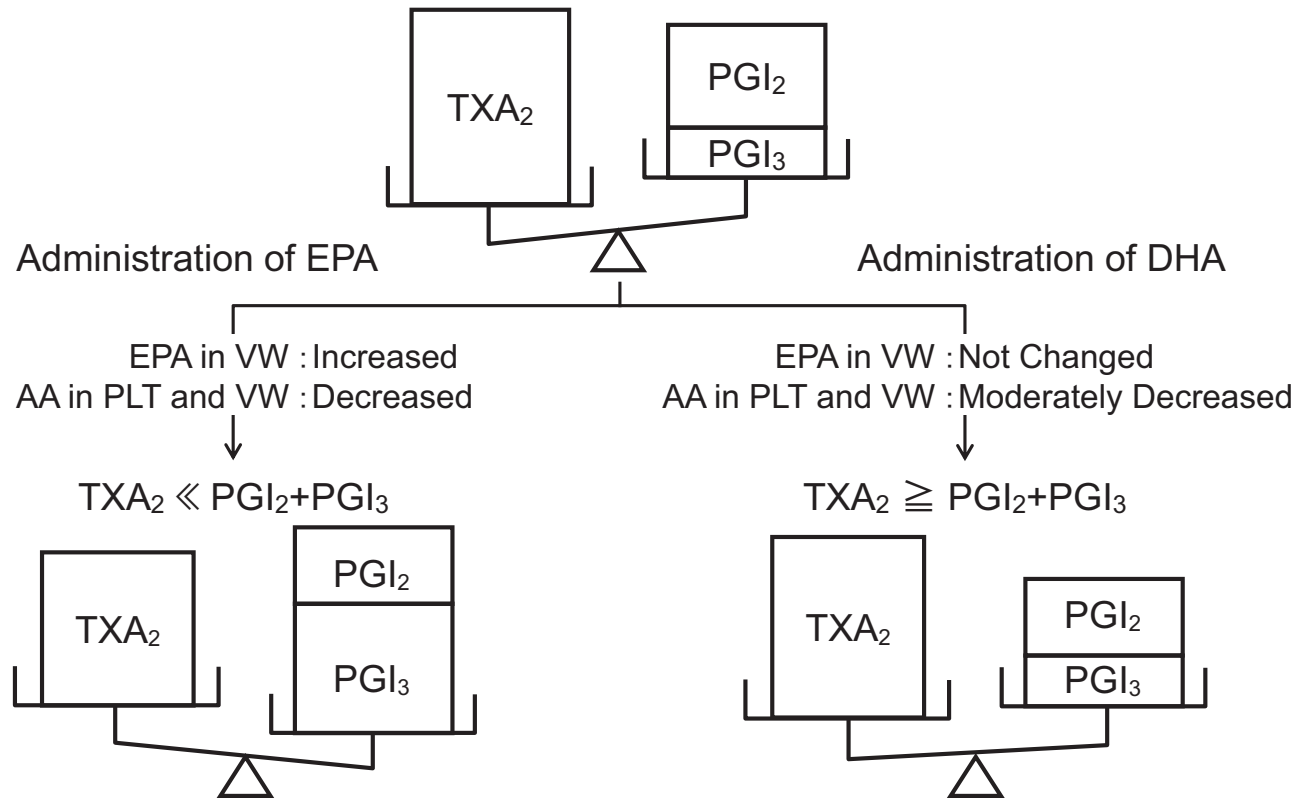

CVD: Cardiovascular Disease, PLT: Platelets, VW: Vessel wall

Fig. 4. Schematic view of balance between prostaglandin $\mathrm{I}_{2,3}$ and thromboxane $\mathrm{A}_{2}$.

triggered by EPA administration. Consequently, the percentage decrease in $\mathrm{TXA}_{2}$ and $\mathrm{PGI}_{2}$ is smaller than that observed when EPA is administered. Changes in the cell membrane EPA content are also minimal, and the $\mathrm{PGI}_{3}$ production does not change. The improvement in the $\left(\mathrm{PGI}_{2}+\mathrm{PGI}_{3}\right) / \mathrm{TXA}_{2}$ ratio is small or negligible following DHA administration as compared to that observed following EPA administration (Fig.4).

\section{Relationship between the (PGI $\left.2+\mathrm{PGI}_{3}\right) / \mathrm{TXA}_{2}$ and EPA/AA Ratios}

Several reports have described a reduced incidence of cardiovascular events associated with an increased EPA/AA ratio. For instance, the incidence of post-PCI cardiac events is negatively associated with the blood EPA/AA ratio (HR: 0.52, $p=0.048$ ) but not the blood DHA/AA ratio (HR: $0.89, p=0.73)^{24)}$. In the JELIS study, the administration of hp-EPA-E $\left(\right.$ Epadel $\left.^{\circledR}\right)$ and statins in hypercholesterolemia patients resulted in a significant reduction in the risk of coronary events when the EPA/AA ratio was $>0.75$ (HR: $0.83, p=0.031)^{20)}$. These findings led to growing interest in the relationship between the EPA/AA and $\left(\mathrm{PGI}_{2}+\mathrm{PGI}_{3}\right) / \mathrm{TXA}_{2}$ ratios.

Representing the blood vessel wall EPA level as EPAa, the blood vessel wall AA level as AAa and the platelet AA level as AAp and assuming that $\mathrm{PGI}_{3}$, $\mathrm{PGI}_{2}$ and $\mathrm{TXA}_{2}$ are produced proportionately to these levels, the $\mathrm{PGI}_{3}$ level can be expressed as $\alpha * \mathrm{EPAa}$, the $\mathrm{PGI}_{2}$ level as $\beta * \mathrm{AAa}$ and the TXA2 level as $\gamma * \mathrm{AAp}$ (*shows multiplication). The following formula is thus established:

$$
\begin{aligned}
&\left(\mathrm{PGI}_{2}+\mathrm{PGI}_{3}\right) / \mathrm{TXA}_{2} \\
&=(\beta * \mathrm{AAa}+\alpha * \mathrm{EPAa}) / \gamma * \mathrm{AAp} \\
&= \beta * \mathrm{AAa} / \gamma * \mathrm{AAp}+\alpha * \mathrm{EPAa} / \gamma * \mathrm{AAp} \\
&= \beta / \gamma * \mathrm{AAa} / \mathrm{AAp}+\alpha / \gamma * \mathrm{EPAa} / \mathrm{AAp} \\
& \text { where } \beta / \gamma \text { and } \alpha / \gamma \text { are constants. Assum- } \\
& \text { ing that AAa/AAp are definite numbers, } \\
& \text { if they are substituted by } \delta, \varepsilon \text { and } \eta, \text { respec- } \\
& \text { tively, } \\
&= \delta * \eta+\varepsilon *(\mathrm{EPAa} / \mathrm{AAp}) \\
& \text { Assuming that EPAa and AAp are propor- } \\
& \text { tionate to the blood phospholipid EPA and } \\
& \text { AA levels, } \\
&= \delta * \eta+\varepsilon *(\theta \mathrm{EPA} / \kappa \mathrm{AA}) \\
&= \delta * \eta+\varepsilon * \theta / \kappa *(\mathrm{EPA} / \mathrm{AA}) \\
& \text { Assuming that } \delta * \mathrm{x} \eta \text { and } \varepsilon * \mathrm{x} \theta / \kappa \text { are def- } \\
& \text { inite numbers expressed as } \lambda \text { and } \pi, \\
&= \lambda+\pi *(\mathrm{EPA} / \mathrm{AA})
\end{aligned}
$$

The formula $\left(\mathrm{PGI}_{2}+\mathrm{PGI}_{3}\right) / \mathrm{TXA}_{2}=\lambda+\pi *(\mathrm{EPA} /$ $\mathrm{AA})$ proves that the $\left(\mathrm{PGI}_{2}+\mathrm{PGI}_{3}\right) / \mathrm{TXA}_{2}$ ratio can be 


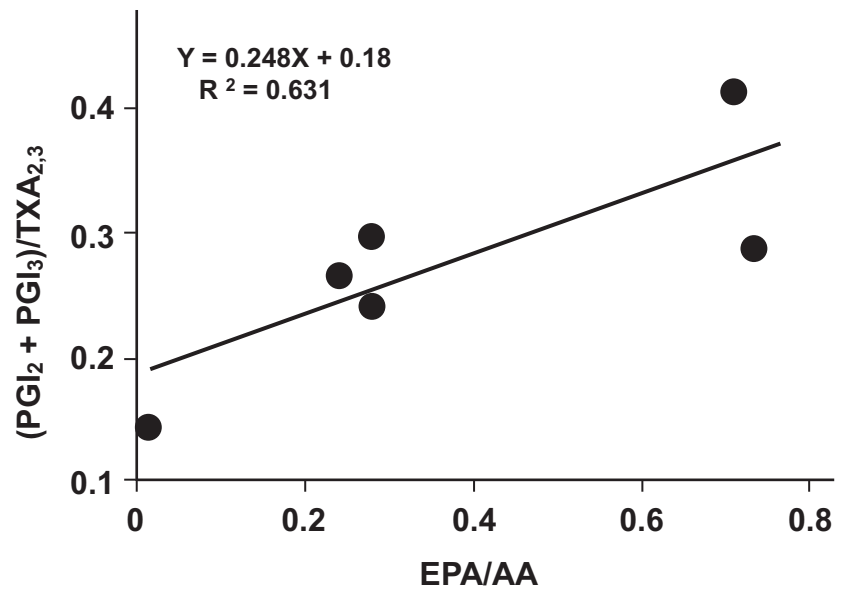

Fig. 5. Relation between EPA/AA ratio and (prostaglandin $I_{2}$ + prostaglandin $\mathrm{I}_{3}$ )/TXA2, 3 ratio. The graph is drawn from results of reference 13 and 94 .

expressed as a linear function of the EPA/AA ratio. Based on the findings of Fischer ${ }^{13)}$ and Hamazaki ${ }^{94)}$ and by plotting the $\mathrm{PGI}_{2}+\mathrm{PGI}_{3} / \mathrm{TXB}_{2,3}$ ratio on the $y$-axis and the EPA/AA ratio on the $\mathrm{x}$-axis, we obtained the regression line shown in Fig. 5. Although it is difficult to plot the platelet EPA/AA ratio and the red blood cell EPA/AA ratio on the same graph, it is evident that the $\left(\mathrm{PGI}_{2}+\mathrm{PGI}_{3}\right) / \mathrm{TXB}_{2,3}$ ratio and $\mathrm{EPA} / \mathrm{AA}$ ratio have a significant linear relationship, which supports the formula expressed above. In other words, the $\mathrm{EPA} / \mathrm{AA}$ ratio reflects the $\left(\mathrm{PGI}_{2}+\mathrm{PGI}_{3}\right) / \mathrm{TXA}_{2}$ ratio, i.e., the PGI/TXA balance. As mentioned above, the EPA/AA ratio has been shown to increase to 0.13 with DHA treatment $(1.62 \mathrm{~g} / \text { day })^{40)}$ and to 0.486 with hpEPA-E treatment ${ }^{20)}$. Therefore, the contribution of EPA to the increase in the PGI/TXA ratio by EPA is greater than that of DHA.

\section{Relationship between the (PGI $\left.2+\mathrm{PGI}_{3}\right) / \mathrm{TXA}_{2}$ Ratio and CRP}

C-reactive protein (CRP) reduces the expression of $\mathrm{PGI}_{2}$ synthetase by human umbilical vein endothelial cells ${ }^{95)}$ and decreases $\mathrm{PGI}_{2}$ release from human artery endothelial cells ${ }^{96)}$. Thermally modified CRP promotes TXA 2 production by platelets ${ }^{97)}$. CRP is a predictor of urinary $\mathrm{d}-\mathrm{TXB}_{2}$ in hypercholesterolemic patients given statins ${ }^{98)}$. Therefore, CRP reduces the $\left(\mathrm{PGI}_{2}+\mathrm{PGI}_{3}\right) / \mathrm{TXA}_{2}$ ratio, shifting the PGI/TXA balance towards the development and progression of cardiac disease and moving the regression line downwards (Fig. 5). In contrast, the plasma high-sensitivity CRP and EPA concentrations exhibit a negative correlation ${ }^{99)}$. The administration of hp-EPA-E (Epadel ${ }^{\circledR}, 1.8$ $\mathrm{g} / \mathrm{d}$ ) increased the EPA/AA ratio in metabolic syn-

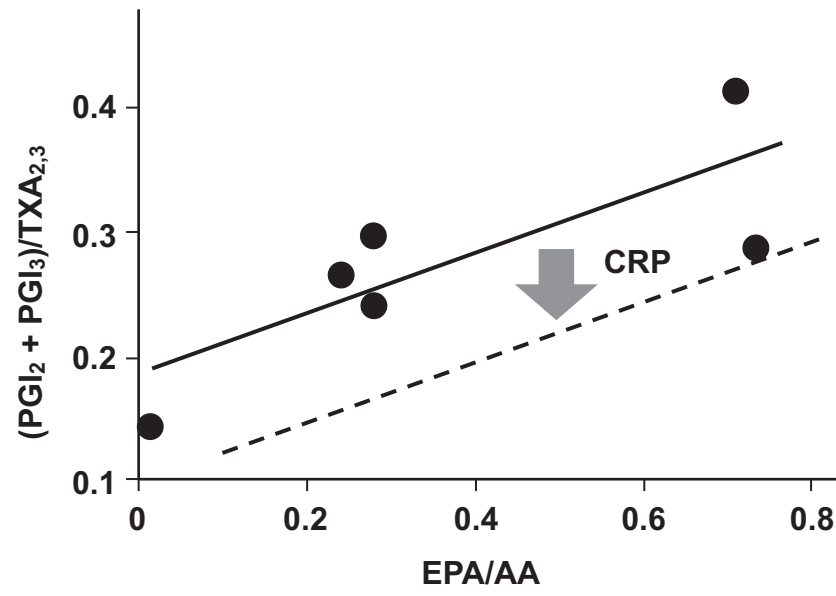

Fig. 6. Influence of CRP on relation between EPA/AA ratio and (prostaglandin $\mathrm{I}_{2}+$ prostaglandin $\mathrm{I}_{3}$ ) $/ \mathrm{TXA}_{2,3}$ ratio.

drome patients from 0.48 to 0.88 and decreased the CRP levels from 0.22 to $0.08^{100)}$. EPA medication decreased the CRP level and increased the EPA/AA ratio. Taken together, the shift of the PGI/TXA balance toward CVD was suppressed by the EPA-induced increase in the EPA/AA ratio (the line was shifted upward) and the decrease in the CRP level (the line was shifted downward) (Fig. 6). In addition, aggravation of the PGI/TXA balance may be considered an action of CRP. In contrast, Burns et al. reported that the blood EPA/AA ratio in patients with coronary disease rose from 0.042 to 0.097 following fish oil intake, while the CRP level did not change ${ }^{101}$. Although this discrepancy in findings cannot be explained, it may be related to the very low EPA/AA ratio.

\section{Significance of the (PGI $\left.2+\mathrm{PGI}_{3}\right) / \mathrm{TXA}_{2}$ and EPA/ AA Ratios}

Based on the finding that the onset and/or progression of CVD is associated with the $\left(\mathrm{PGI}_{2}+\mathrm{PGI}_{3}\right) /$ $\mathrm{TXA}_{2}$ and EPA/AA ratios, the PGI-TXA balance may explain the inhibition of cardiovascular events induced by aspirin and PGI 2 analogs and the onset of cardiovascular events induced by cyclooxygenase- 2 inhibitors. In summary, it is important to increase the PGI/ TXA ratio in order to reduce the incidence of cardiovascular events. Improvements in the $\left(\mathrm{PGI}_{2}+\mathrm{PGI}_{3}\right) /$ $\mathrm{TXA}_{2}$ ratio, namely the EPA/AA ratio, may contribute to reducing the frequency of cardiovascular events with EPA administration.

\section{Conclusion}

Dyerberg and colleagues examined the relation- 
ship between EPA and CVD, and the JELIS study recently demonstrated that EPA administration reduces the risk of CVD. An important difference between EPA and DHA is the metabolism of EPA to bioactive PGI 3 . It is assumed that, similar to $\mathrm{PGI}_{2}$, $\mathrm{PGI}_{3}$ inhibits platelet aggregation, vascular contraction, myocardial ischemic injury and arteriosclerosis and induces neoangiogenesis. Therefore, it is speculated that the CVD risk reduction induced by EPA is also associated with the effects of $\mathrm{PGI}_{3}$ in addition to the numerous effects of EPA itself (such as TG reduction, inflammation inhibition and improvements in plasma membrane fluidity). This hypothesis is confirmed by the following findings: an increased CVD risk was found to be associated with a reduction in the EPA/AA ratio, and the EPA/AA ratio was found to be positively correlated with the $\left(\mathrm{PGI}_{2}+\mathrm{PGI}_{3}\right) / \mathrm{TXA}_{2}$ ratio.

\section{Conflicts of Interest}

None.

\section{References}

1) Gorjāo R, Azevedo-Martins AK, Rodrigues HG, Abdulkader F, Arcisio-Miranda M, Procopio J, Curi R: Comparative effects of DHA and EPA on cell function. Pharmacol Ther, 2009; 122: 56-64

2) Arterburn LM, Hall EB, Oken H: Distribution, interconversion, and dose response of n-3 fatty acids in humans. Am J Clin Nutr, 2006; 83: 1467S-1476S

3) Hooper L, Thompson RL, Harrison RA, Summerbell CD, Ness AR, Moore HJ, Worthington HV, Durrington PN, Higgins JP, Capps NE, Riemersma RA, Ebrahim SB, Davey Smith G: Risks and benefits of omega 3 fats for mortality, cardiovascular disease, and cancer: systematic review. BMJ, 2006; 332: 752-760

4) Tolonen MJ: Responses to "BMJ. 2006 Apr 1; 332 (7544): 752-60". 2 April 2006. http: //www.bmj.com/ content $/ 332 / 7544 / 752$ ? page $=1 \&$ tab $=$ responses

5) Ahrens EH Jr, Insull W Jr, Hirsch J, Stoffel W, Peterson ML, Farquhar JW, Iller T, Thomasson HJ: The effect on human serum-lipids of a dietary fat, highly unsaturated, but poor in essential fatty acids. Lancet, 1959; 1: 115119

6) Kinsell LW, Michaels GD, Walker G, Visintine RE: The effect of a fish-oil fraction on plasma lipids. Diabetes, 1961; 10: 316-319

7) Hegsted DM, Jack CW, Stare FJ: The composition of human adipose tissue from several parts of the world. Am J Clin Nutr, 1962; 10: 11-18

8) Nelson AM: Diet therapy in coronary disease: effect on mortality of high-protein, high-seafood, fat-controlled diet. Geriatrics, 1972; 27: 103-116

9) Bang HO, Dyerberg J, Nielsen AB: Plasma lipid and lipoprotein pattern in Greenlandic West-coast Eskimos. Lancet, 1971; 1: 1143-1145

10) Dyerberg J, Bang HO, Hjorne N: Fatty acid composition of the plasma lipids in Greenland Eskimos. Am J Clin Nutr, 1975; 28: 958-966

11) Bang HO, Dyerberg J, Hjøorne N: The composition of food consumed by Greenland Eskimos. Acta Med Scand, 1976; 200: 69-73

12) Dyerberg J, Bang HO, Stoffersen E, Moncada S, Vane JR: Eicosapentaenoic acid and prevention of thrombosis and atherosclerosis? Lancet, 1978; 2: 117-119

13) Fischer S, Weber PC, Dyerberg J: The prostacyclin/ thromboxane balance is favourably shifted in Greenland Eskimos. Prostaglandins, 1986; 32: 235-241

14) Kromann N, Green A: Epidemiological studies in the Upernavik district, Greenland. incidence of some chronic diseases 1950-1974. Acta Med Scand, 1980; 208: 401 406

15) Hirai A, Hamazaki T, Terano T, Nishikawa T, Tamura $Y$, Kumagai A, Jajiki J: Eicosapentaenoic acid and platelet function in Japanese. Lancet, 1980; 2: 1132-1133

16) Hirai A: An epidemiological study on the dietary ingestion of eicosapentaenoic acid (EPA) and platelet function in Japanese. Nihon Naika Gakkai Zasshi, 1985; 74: $13-20$

17) Dolecek TA: Epidemiological evidence of relationships between dietary polyunsaturated fatty acidsand mortality in the multiple risk factor intervention trial. Proc Soc Exp Biol Med, 1992; 200: 177-182

18) Iso H, Rexrode KM, Stampfer MJ, Manson JE, Colditz GA, Speizer FE, Hennekens CH, Willett WC: Intake of fish and omega-3 fatty acids and risk of stroke in women. JAMA, 2001; 285: 304-312

19) Gissi-HF Investigators, Tavazzi L, Maggioni AP, Marchioli R, Barlera S, Franzosi MG, Latini R, Lucci D, Nicolosi GL, Porcu M, Tognoni G: Effect of n-3 polyunsaturated fatty acids in patients with chronic heart failure (the GISSI-HF trial): a randomised, double-blind, placebo-controlled trial. Lancet, 2008; 372: 1223-1230

20) Yokoyama M, Origasa H, Matsuzaki M, Matsuzawa $Y$, Saito Y, Ishikawa Y, Oikawa S, Sasaki J, Hishida H, Itakura H, Kita T, Kitabatake A, Nakaya N, Sakata T, Shimada K, Shirato K: Japan EPA lipid intervention study (JELIS) Investigators. Effects of eicosapentaenoic acid on major coronary events in hypercholesterolaemic patients (JELIS): a randomised open-label, blinded endpoint analysis. Lancet, 2007; 369: 1090-1098

21) Itakura $H$, Yokoyama $M$, Matsuzaki $M$, Saito $Y$, Origasa H, Ishikawa Y, Oikawa S, Sasaki J, Hishida H, Kita T, Kitabatake A, Nakaya N, Sakata T, Shimada K, Shirato $\mathrm{K}$, Matsuzawa Y: JELIS Investigators. Relationships between plasma fatty acid composition and coronary artery disease. J Atheroscler Thromb, 2011; 18: 99-107

22) Mozaffarian D, Lemaitre RN, King IB, Song $X$, Spiegelman D, Sacks FM, Rimm EB, Siscovick DS: Circulating long-chain $\omega-3$ fatty acids and incidence of congestive heart failure in older adults: the cardiovascular health study, Ann Intern Med, 2011 155: 160-170

23) Lee SH, Shin MJ, Kim JS, Ko YG, Kang SM, Choi D, Jang Y, Chung N, Shim WH, Cho SY, Manabe I, Ha 
JW: Blood eicosapentaenoic acid and docosahexaenoic acid as predictors of all-cause mortality in patients with acute myocardial infarction--data from Infarction Prognosis Study (IPS) Registry. Circ J, 2009; 73: 2250-2257

24) Domei T, Yokoi H, Kuramitsu S, Soga Y, Arita T, Ando K, Shirai S, Kondo K, Sakai K, Goya M, Iwabuchi M, Ueeda M, Nobuyoshi M: Ratio of serum n-3 to n-6 polyunsaturated fatty acids and the incidence of major adverse cardiac events in patients undergoing percutaneous coronary intervention. Circ J, 2012; 76: 423-429

25) Yamagishi K, Nettleton JA, Folsom AR: ARIC Study Investigators. Plasma fatty acid composition and incident heart failure in middle-aged adults: the Atherosclerosis Risk in Communities (ARIC) Study, Am Heart J, 2008; 156: 965-974

26) Broekman MJ, Ward JW, Marcus AJ: Phospholipid metabolism in stimulated human platelets. Changes in phosphatidylinositol, phosphatidic acid, and lysophospholipids. J Clin Invest, 1980; 66: 275-283

27) Fischer S, von Schacky C, Siess W, Strasser T, Weber PC: Uptake, release and metabolism of docosahexaenoic acid (DHA, c22: 6 omega 3) in human platelets and neutrophils. Biochem Biophys Res Commun, 1984; 120: 907918

28) Mahadevappa VG, Holub BJ: Quantitative loss of individual eicosapentaenoyl-relative to arachidonoyl-containing phospholipids in thrombin-stimulated human platelets. J Lipid Res, 1987; 28: 1275-1280

29) Weaver BJ, Holub BJ: The relative degradation of [14C] eicosapentaenoyl and $[3 \mathrm{H}]$ arachidonoyl species of phosphatidylinositol and phosphatidylcholine in thrombinstimulated human platelets. Biochem Cell Biol, 1986; 64: 1256-1261

30) Kazachkov M, Chen Q, Wang L. Zou J. Substrate preferences of a lysophosphatidylcholine acyltransferase highlight its role in phospholipid remodeling.Lipids. 2008; 43: 895-902

31) Iritani N, Ikeda Y, Kajitani H: Selectivities of 1-acylglycerophosphorylcholine acyltransferase and acyl-CoA synthetase for $n-3$ polyunsaturated fatty acids in platelets and liver mirosomes. Biochim Biophys Acta, 1984; 793: 416-422

32) Takamura H, Kasai H, Arita H, Kito M: Phospholipid molecular species in human umbilical artery and vein endothelial cells. J Lipid Res, 1990; 31: 709-717

33) Murphy EJ, Joseph L, Stephens R, Horrocks LA: Phospholipid composition of cultured human endothelial cells. Lipids, 1992; 27: 150-153

34) Jamin SP, Crabos M, Catheline M, Martin-Chouly C, Legrand AB, Saïag B: Eicosapentaenoic acid reduces thrombin-evoked release of endothelin-1 in cultured bovine endothelial cells. Res Commun Mol Pathol Pharmacol, 1999; 105: 271-281

35) Martin TW, Michaelis KC: Ca2(+)-dependent synthesis of prostaglandin $\mathrm{I} 2$ and mobilization of arachidonic acid from phospholipids in cultured endothelial cells permeabilized with saponin. Biochim Biophys Acta, 1990; 1054: 159-168

36) Arterburn LM, Hall EB, Oken H: Distribution, interconversion, and dose response of $n-3$ fatty acids in humans. Am J Clin Nutr, 2006; 83: 1467S-1476S

37) Hansen JB, Grimsgaard S, Nilsen H, Nordoy A, Bonaa $\mathrm{KH}$ : Effects of highly purified eicosapentaenoic acid and docosahexaenoic acid on fatty acid absorption, incorporation into serum phospholipids and postprandial triglyceridemia. Lipids, 1998; 33: 131-138

38) Mori TA, Burke V, Puddey IB, Watts GF, O’Neal DN, Best JD, Beilin LJ: Purified eicosapentaenoic and docosahexaenoic acids have differential effects on serum lipids and lipoproteins, LDL particle size, glucose, and insulin in mildly hyperlipidemic men. Am J Clin Nutr, 2000; 71: 1085-1094

39) Itakura H, Yokoyama M, Matsuzaki M, Saito Y, Origasa H, Ishikawa Y, Oikawa S, Sasaki J, Hishida H, Kita T, Kitabatake A, Nakaya N, Sakata T, Shimada K, Shirato K, Matsuzawa Y: Relationships between plasma fatty acid composition and coronary artery disease. J Atheroscler Thromb, 2011; 18: 99-107

40) Conquer JA, Holub BJ: Supplementation with an algae source of docosahexaenoic acid increases (n-3) fatty acid status and alters selected risk factors for heart disease in vegetarian subjects. J Nutr, 1996; 126: 3032-3039

41) Brossard N, Croset M, Pachiaudi C, Riou JP, Tayot JL, Lagarde M: Retroconversion and metabolism of [13C]22: 6n-3 in humans and rats after intake of a single dose of [13C]22: 6n-3-triacylglycerols. Am J Clin Nutr, 1996; 64: 577-586

42) Gerster $\mathrm{H}$ : Can adults adequately convert alpha-linolenic acid (18: 3n-3) to eicosapentaenoic acid (20: 5n-3) and docosahexaenoic acid (22: 6n-3)? Int J Vitam Nutr Res, 1998; 68: 159-173

43) Crawford MA, Bloom M, Broadhurst CL, Schmidt WF, Cunnane SC, Galli C, Gehbremeskel K, Linseisen F, Lloyd-Smith J, Parkington J: Evidence for the unique function of docosahexaenoic acid during the evolution of the modern hominid brain. Lipids, 1999; 34 Suppl: S39-47

44) DeMar JC Jr, Ma K, Bell JM, Rapoport SI: Half-lives of docosahexaenoic acid in rat brain phospholipids are prolonged by 15 weeks of nutritional deprivation of n-3 polyunsaturated fatty acids. J Neurochem, 2004; 91: 1125-1137

45) Crawford MA: Docosahexaenoic acid in neural signaling systems. Nutr Health, 2006; 18: 263-276

46) Long EK, Murphy TC, Leiphon LJ, Watt J, Morrow JD, Milne GL, Howard JR, Picklo MJ Sr: Trans-4-hydroxy2-hexenal is a neurotoxic product of docosahexaenoic (22: 6; n-3) acid oxidation. J Neurochem, 2008; 105: 714-724

47) Bradley MA, Xiong-Fister S, Markesbery WR, Lovell MA; Elevated 4-hydroxyhexenal in Alzheimer's disease (AD) progression. Neurobiol Aging. 2012; 33: 10341044

48) Thies F, Garry JM, Yaqoob P, Rerkasem K, Williams J, Shearman CP, Gallagher PJ, Calder PC, Grimble RF: Association of $n-3$ polyunsaturated fatty acids with stability of atherosclerotic plaques: a randomised controlled trial. Lancet, 2003; 361: 477-485

49) Cawood AL, Ding R, Napper FL, Young RH, Williams JA, Ward MJ, Gudmundsen O, Vige R, Payne SP, Ye S, 
Shearman CP, Gallagher PJ, Grimble RF, Calder PC: Eicosapentaenoic acid (EPA) from highly concentrated n-3 fatty acid ethyl esters is incorporated into advanced atherosclerotic plaques and higher plaque EPA is associated with decreased plaque inflammation and increased stability. Atherosclerosis, 2010; 212: 252-259

50) Harris WS, Sands SA, Windsor SL, Ali HA, Stevens TL, Magalski A, Porter CB, Borkon AM: Omega-3 fatty acids in cardiac biopsies from heart transplantation patients: correlation with erythrocytes and response to supplementation. Circulation, 2004; 110: 1645-1649

51) Metcalf RG, James MJ, Gibson RA, Edwards JR, Stubberfield J, Stuklis R, Roberts-Thomson K, Young GD, Cleland LG: Effects of fish-oil supplementation on myocardial fatty acids in humans. Am J Clin Nutr, 2007; 85: $1222-1228$

52) Futata T,Asano T,Meng J, Kan K, Okumura M, Miwa $\mathrm{H}$ : Platelet aggregation, thromboxane A2 formation, fatty acid composition in plasma, and platelet phospholipids in patients with NIDDM (the effect of EPA-E). Ann Japan Soc Res Diab Complicat, 1996; 9: 31-37

53) Di Stasi D, Bernasconi R, Marchioli R, Marfisi RM, Rossi G, Tognoni G, Tacconi MT: Early modifications of fatty acid composition in plasma phospholipids, platelets and mononucleates of healthy volunteers after low doses of n-3 polyunsaturated fatty acids. Eur J Clin Pharmacol, 2004; 60: 183-190

54) Johnson RA, Lincoln FH, Nidy EG, Schneider WP, Thompson JL, Axen U: Synthesis and characterization of prostacyclin, 6-ketoprostaglandin F1.alpha., prostaglandin I1, and prostaglandin I3. J Am Chem Soc, 1978; 100: 7690-7705

55) Whitaker MO, Wyche A, Fitzpatrick F, Sprecher H, Needleman P: Triene prostaglandins: prostaglandin D3 and icosapentaenoic acid as potential antithrombotic substances. Proc Natl Acad Sci U S A, 1979; 76: 5919-5923

56) Onodera M, Morita, Mano Y, Murota S: Differential effects of nitric oxide on the activity of prostaglandin endoperoxide $\mathrm{H}$ synthase- 1 and -2 in vascular endothelial cells. Prostaglandins Leukot Essent Fatty Acids, 2000; 62: 161-167

57) Niwano K, Arai M, Tomaru K, Uchiyama T, Ohyama Y, Kurabayashi M: Transcriptional stimulation of the eNOS gene by the stable prostacyclin analogue beraprost is mediated through cAMP-responsive element in vascular endothelial cells: close link between PGI2 signal and NO pathways. Circ Res, 2003; 93: 523-530

58) Hardy P, Abran D, Hou X, Lahaie I, Peri KG, Asselin P, Varma DR, Chemtob S: A major role for prostacyclin in nitric oxide-induced ocular vasorelaxation in the piglet. Circ Res, 1998; 83: 721-729

59) Li Q, Zhang Q, Wang M, Zhao S, Ma J, Luo N, Li N, Li Y, Xu G, Li J: Eicosapentaenoic acid modifies lipid composition in caveolae and induces translocation of endothelial nitric oxide synthase. Biochimie, 2007; 89: 169-177

60) Höper MM, Voelkel NF, Bates TO, Allard JD, Horan M, Shepherd D, Tuder RM: Prostaglandins induce vascular endothelial growth factor in a human monocytic cell line and rat lungs via cAMP. Am J Respir Cell Mol
Biol, 1997; 17: 748-756

61) Wheeler-Jones C, Abu-Ghazaleh R, Cospedal R, Houliston RA, Martin J, Zachary I: Vascular endothelial growth factor stimulates prostacyclin production and activation of cytosolic phospholipase A2 in endothelial cells via $\mathrm{p} 42 / \mathrm{p} 44$ mitogen-activated protein kinase. FEBS Lett, 1997; 420: 28-32

62) Santhanam AV, Smith LA, He T, Nath KA, Katusic ZS: Endothelial progenitor cells stimulate cerebrovascular production of prostacyclin by paracrine activation of cyclooxygenase-2. Circ Res, 2007; 100: 1379-1388

63) Ashton AW, Ware JA: Thromboxane A2 receptor signaling inhibits vascular endothelial growth factor-induced endothelial cell differentiation and migration. Circ Res, 2004; 95: 372-379

64) Hirata Y, Shimabukuro M, Uematsu E, Soeki T, Yamada H, Sakai Y, Nakayama M, Matsumoto K, Igarashi T, Sata M: A synthetic prostacyclin agonist with thromboxane synthase inhibitory activity, ONO-1301, protects myocardium from ischemia/reperfusion injury. Eur J Pharmacol, 2012; 674: 352-358

65) Krishnamurthy P, Bird IM, Sheppard C, Magness RR: Effects of angiogenic growth factors on endotheliumderived prostacyclin production by ovine uterine and placental arteries. Prostaglandins Other Lipid Mediat, 1999; 57: 1-12

66) Tongers J, Roncalli JG, Losordo DW: Role of endothelial progenitor cells during ischemia-induced vasculogenesis and collateral formation. Microvasc Res, 2010; 79: 200-206

67) He T, Lu T, d'Uscio LV, Lam CF, Lee HC, Katusic ZS: Angiogenic function of prostacyclin biosynthesis in human endothelial progenitor cells. Circ Res, 2008; 103: 80-88

68) Kawabe J, Yuhki K, Okada M, Kanno T, Yamauchi A, Tashiro N, Sasaki T, Okumura S, Nakagawa N, Aburakawa Y, Takehara N, Fujino T, Hasebe N, Narumiya S, Ushikubi F: Prostaglandin I2 promotes recruitment of endothelial progenitor cells and limits vascular remodeling. Arterioscler Thromb Vasc Biol, 2010; 30: $464-470$

69) Di Stefano R, Barsotti MC, Melillo E, Iorio M, Santoni T, Armani C, Dell'omodarme M, Ristori C, De Caterina $\mathrm{R}$, Balbarini A: The prostacyclin analogue iloprost increases circulating endothelial progenitor cells in patients with critical limb ischemia. Thromb Haemost, 2008; 100: 871-877

70) Kobayashi N, Takeshima H, Koguchi W, Ishikawa M, Sugiyama F, Onoda S, Ishimitsu T: Effect of combination therapy with bonemarrow mononuclear cells implantation and eicosapentaenoic acid on angiogenesis in myocardial ischemia. J Hypertension. 2012; 30 (e-supplement 1): 260

71) Endo M, Iwa T, Urayama H, Nagai A, Sawa S, Kuroda $Y$, Iida S, Hashiba A, Murakita K, Ichihashi T, Saito H, Murakami S: The multi-institutional clinical study of the effect and safety of ethyl Icosapentate on arteriosclerosis obliterans. Japanese College Angiology, 1992; 32: $233-238$

72) Kanayasu T, Morita I, Nakao-Hayashi J, Asuwa N, Fuji- 
sawa C, Ishii T, Ito H, Murota S: Eicosapentaenoic acid inhibits tube formation of vascular endothelial cells in vitro. Lipids, 1991; 26: 271-276

73) Kim HJ, Vosseler CA, Weber PC, Erl W: Docosahexaenoic acid induces apoptosis in proliferating human endothelial cell. J Cell Physiol, 2005; 204: 881-888

74) Spencer L, Mann C, Metcalfe M, Webb M, Pollard C, Spencer D, Berry D, Steward W, Dennison A: The effect of omega-3 FAs on tumour angiogenesis and their therapeutic potential.Eur J Cancer, 2009; 45: 2077-86

75) Reiss AB, Edelman SD: Recent insights into the role of prostanoids in atherosclerotic vascular Disease. Curr Vasc Pharmacol, 2006; 4: 395-408

76) Numaguchi $Y$, Naruse $K$, Harada M, Osanai $H$, Mokuno S, Murase K, Matsui H, Toki Y, Ito T, Okumura K, Hayakawa T: Prostacyclin synthase gene transfer accelerates reendothelialization and inhibits neointimal formation in rat carotid arteries after balloon injury. Arterioscler Thromb Vasc Biol, 1999; 19: 727-733

77) Cheng Y, Austin SC, Rocca B, Koller BH, Coffman TM, Grosser T, Lawson JA, FitzGerald GA: Role of prostacyclin in the cardiovascular response to thromboxane $\mathrm{A} 2$. Science, 2002; 296: 539-541

78) Thomas DW, Mannon RB, Mannon PJ, Latour A, Oliver JA, Hoffman M, Smithies O, Koller BH, Coffman TM: Coagulation defects and altered hemodynamic responses in mice lacking receptors for thromboxane A2. J Clin Invest, 1998; 102: 1994-2001

79) Gabrielsen A, Qiu H, Bäck M, Hamberg M, Hemdahl AL, Agardh H, Folkersen L, Swedenborg J, Hedin U, Paulsson-Berne G, Haeggstrom JZ, Hansson GK: Thromboxane synthase expression and thromboxane A2 production in the atherosclerotic lesion. J Mol Med (Berl), 2010; 88: 795-806

80) Kobayashi T, Tahara Y, Matsumoto M, Iguchi M, Sano $\mathrm{H}$, Murayama T, Arai H, Oida H, Yurugi-Kobayashi T, Yamashita JK, Katagiri H, Majima M, Yokode M, Kita T, Narumiya S: Roles of thromboxane $\mathrm{A}(2)$ and prostacyclin in the development of atherosclerosis in apoE-deficient mice. J Clin Invest, 2004; 114: 784-794

81) Yamada H, Yoshida M, Nakano Y, Suganami T, Satoh N, Mita T, Azuma K, Itoh M, Yamamoto Y, Kamei Y, Horie $\mathrm{M}$, Watada $\mathrm{H}$, Ogawa $\mathrm{Y}$ : In vivo and in vitro inhibition of monocyte adhesion to endothelial cells and endothelial adhesion molecules by eicosapentaenoic acid, Arterioscler Thromb Vasc Biol, 2008; 28: 2173-2179

82) Collie-Duguid ES, Wahle KW: Inhibitory effect of fish oil N-3 polyunsaturated fatty acids on the expression of endothelial cell adhesion molecules, Biochem Biophys Res Commun, 1996; 220: 969-974

83) Watanabe I, Nagao K, Wang DY, Akutsu N, Shioiri K, Ohiwa K, Kikushima K, Kanmatsuse K: Usefulness of EPA-E(Eicosapentaenoic Acid Ethyl Ester) in preventing formation after vascular injury. Kokyu to Junkan, 1994; 42: 673-677

84) Nestel P, Shige H, Pomeroy S, Cehun M, Abbey M, Raederstorff D: The n-3 fatty acids eicosapentaenoic acid and docosahexaenoic acid increase systemic arterial compliance in humans. Am J Clin Nutr, 2002; 76: 326-30

85) Coker SJ, Parratt JR, Ledingham IM, Zeitlin IJ: Throm- boxane and prostacyclin release from ischaemic myocardium in relation to arrhythmias. Nature, 1981; 291: 323-324

86) Xiao CY, Hara A, Yuhki K, Fujino T, Ma H, Okada Y, Takahata O, Yamada T, Murata T, Narumiya S, Ushikubi F: Roles of prostaglandin I(2) and thromboxane $\mathrm{A}(2)$ in cardiac ischemia-reperfusion injury: a study using mice lacking their respective receptors. Circulation, 2001; 104: 2210-2215

87) Neri Serneri GG, Modesti PA, Fortini A, Abbate R, Lombardi A, Gensini GF: Reduction in prostacyclin platelet receptors in active spontaneous angina. Lancet, 1984; 2: 838-841

88) Hara A, Yuhki K, Fujino T, Yamada T, Takayama K, Kuriyama S, Takahata O, Karibe H, Okada Y, Xiao CY, Ma H, Narumiya S, Ushikubi F: Augmented cardiac hypertrophy in response to pressure overload in mice lacking the prostaglandin I2 receptor. Circulation, 2005; 112: 84-92

89) Gao JY, Yasuda S, Tsuburaya R, Ito Y, Shiroto T, Hao K, Aizawa K, Kikuchi Y, Ito K, Shimokawa H: Long-term treatment with eicosapentaenoic acid ameliorates myocardial ischemia-reperfusion injury in pigs in vivo. -Involvement of Rho-kinase pathway inhibition. Circ J, 2011; 75: 1843-1851

90) Spector AA, Kaduce TL, Figard PH, Norton KC, Hoak JC, Czervionke RL: Eicosapentaenoic acid and prostacyclin production by cultured human endothelial cells. J Lipid Res, 1983; 24: 1595-604

91) Murota S, Morita I: Eicosapentaenoic acid. Journal of clinical and experimental medicine, 1984; 130: 787-798

92) Walsh MT, Foley JF, Kinsella BT: The alpha, but not the beta, isoform of the human thromboxane A2 receptor is a target for prostacyclin-mediated desensitization. J Biol Chem, 2000; 275: 20412-20423

93) Nishio S, Kurumatani H: Pharmacological and clinical properties of beraprost sodium, orally active pprostacyclin analogue. Folia Pharmacol Jpn, 2001; 117: 123-130

94) Hamazaki T, Fischer S, Urakaze M, Sawazaki S, Yano S: Comparison of the urinary metabolites of prostacyclin and thromboxane of the 2- and 3-series in a Japanese fishing and a Japanese farming village. Prostaglandins, 1986; 32: 655-664

95) Grad E, Golomb M, Koroukhov N, Lawson JA, Lotan C, Fitzgerald GA, Danenberg HD: Aspirin reduces the prothrombotic activity of C-reactive protein. J Thromb Haemost, 2009; 7: 1393-1400

96) Venugopal SK, Devaraj S, Jialal I: C-reactive protein decreases prostacyclin release from human aortic endothelial cells. Circulation, 2003; 108: 1676-1678

97) Simpson RM, Prancan A, Izzi JM, Fiedel BA: Generation of thromboxane A2 and aorta-contracting activity from platelets stimulated with modified C-reactive protein. Immunology, 1982; 47: 193-202

98) Puccetti L, Santilli F, Pasqui AL, Lattanzio S, Liani R, Ciani F, Ferrante E, Ciabattoni G, Scarpini F, Ghezzi A, Auteri A, Davì G: Effects of atorvastatin and rosuvastatin on thromboxane-dependent platelet activation and oxidative stress in hypercholesterolemia. Atherosclerosis, 2011; 214: 122-128 
99) Micallef MA, Munro IA, Garg ML: An inverse relationship between plasma n-3 fatty acids and C-reactive protein in healthy individuals. Eur J Clin Nutr, 2009; 63: 1154-1156

100) Satoh N, Shimatsu A, Kotani K, Sakane N, Yamada K, Suganami T, Kuzuya H, Ogawa Y: Purified eicosapentaenoic acid reduces small dense LDL, remnant lipoprotein particles, and C-reactive protein in metabolic syndrome. Diabetes Care, 2007; 30: 144-146

101) Burns T, Maciejewski SR, Hamilton WR, Zheng M, Mooss AN, Hilleman DE: Effect of omega-3 fatty acid supplementation on the arachidonic acid: eicosapentaenoic acid ratio. Pharmacotherapy, 2007; 27: 633-638 